\title{
Artur Duda*
}

\section{Eimuntas Nekrošius i jego teatr zmysłowych metafor}

DOI: http://dx.doi.org/10.12775/LC.2018.019

Streszczenie: Artykul syntetycznie przedstawia najważniejsze etapy kariery litewskiego reżysera Eimuntasa Nekrošiusa - od studiów w moskiewskim GITIS-ie, przez najważniejsze inscenizacje wileńskie, które odzwierciedlają autorski charakter jego pisma teatralnego, po Dziady zrealizowane w Teatrze Narodowym w Warszawie w 2016 roku. Zasadniczą część tekstu stanowi prezentacja tzw. teatru zmysłowych metafor, opartego na autorskim czytaniu klasycznych tekstów, wizualizacji metafor w nich zawartych oraz wykorzystaniu motorycznego ciała aktora.

Słowa kluczowe: teatr Europy Wschodniej, teatr litewski, teatr postdramatyczny, aktorstwo cielesno-performatywne, Eimuntas Nekrošius

\section{Eimuntas Nekrošius and his theatre of sensual metaphors}

\begin{abstract}
The article is a brief presentation of main career stages of Lithuanian director Eimuntas Nekrošius - from his study in the Russian Institute of Theatre Arts (GITIS) in Moscow, through the most important performances in Vilnius, which reflect author's characteristic of his theatre work, to Forefathers' Eve staging in the National Theatre Warsaw in 2016. The core part of the paper is devoted to the presentation of so called "theatre of sensual metaphors" typical of Nekrošius and based on: author's reading of classical dramas, visualizing and materializing metaphors taken from the text and using actor's motoric body.
\end{abstract}

Keywords: East European theatre, Lithuanian theatre, postdramatic theatre, corporeal-performative acting

* Teatrolog, performatyk, kierownik Zakładu Dramatu i Teatru w Katedrze Kulturoznawstwa Uniwersytetu Mikołaja Kopernika. Zajmuje się: relacją między tekstem dramatu a jego inscenizacją, estetyką teatru współczesnego, teatrem polskim, litewskim i niemieckim, performansami na żywo i zmediatyzowanymi. E-mail: dudaart@umk.pl. 
ożna zaryzykować twierdzenie, że od czasów teatru monumentalnego Wilama Horzycy z lat 1945-1948 nie było na scenie toruńskiej większej osobowości teatralnej niż Eimuntas Nekrošius. Co prawda litewski artysta nie zrealizował tu ani jednego spektaklu w repertuarze, pokazał natomiast dziesięć przywiezionych z Litwy znakomitych inscenizacji, w tym dziewięć po raz pierwszy w Polsce. Można by także mnożyć superlatywy pod adresem urodzonego w 1952 roku w małej wiosce Pažobris na Żmudzi, absolwenta moskiewskiego GITIS-u, jednego z najwybitniejszych reżyserów teatru litewskiego i europejskiego drugiej połowy XX wieku. Ale nie pasuje to zbytnio do postaci małomównego, zamkniętego w sobie artysty, który manifestuje wielką wyobraźnię teatralną w swoich scenicznych dziełach. Tak jak wyglądał jako nieśmiały dziewięcioletni chłopiec na czarno-białej fotografii w książce Ramunė Marcinkevičiute, tak też pamiętają go koledzy ze studiów. Dalia Overaitė wspominała po latach:

Siedział w kącie, milczał. Nie chodził na wykłady z innych dziedzin, skupił się tylko na specjalistycznych. Ale kiedy wystawił swoją etiudę według Hiroszima, moja mitość [Marguerite Duras], wielu otworzyły się oczy. Teraz już było wiadomo, że to [genialny] samouk (Marcinkevičiutė 2002: 48).

We wspomnianej etiudzie pojawiła się muzyka Pink Floyd i rekwizyt w postaci piły. W scenie rozwodu mężczyzna i kobieta przepiłowywali drewnianą belkę. Muzyka i proste przedmioty służyły konstruowaniu teatralnej metafory, bliskiej materialnemu światu i wciągającej widza w intensywne zmysłowe doświadczenie. To może nie był jeszcze wielki teatr, ale na pewno zapowiedź mającego się wkrótce ukształtować autorskiego pisma teatralnego Eimuntasa Nekrošiusa.

Debiutował w 1977 roku inscenizacją Smaku miodu irlandzkiej dramatopisarki Shelagh Delaney, zrealizowaną w Państwowym Teatrze Młodzieżowym w Wilnie, po krótkim epizodzie w Kownie wrócił do Wilna. Ramunè Marcinkevičiute uznaje, że tutaj - w latach 19771994 - ukształtowała się autorska estetyka teatru Nekrošiusa, zmaterializowana zwłaszcza w przedstawieniach Kwadrat (na podstawie tekstu Sauliusa Šaltenisa, 1980), Pirosmani, Pirosmani... Wadima Korostyliewa (1981), a także Dzień dłuższy niż stulecie Czingiza Ajtmatowa (1983) i Wujaszek Wania Antona Czechowa (1986). Drugi etap jego twórczości charakteryzujący się licznymi wyjazdami na festiwale zagraniczne to czas współpracy z Festiwalem LIFE (1994-1997) i wreszcie etap trzeci, trwający do dziś: otwarcie własnego teatru Meno Fortas (Fort Sztuki, 1998), w którym poza inscenizacjami Szekspira zrealizował m.in. Fausta Goethego (2006) i Boska komedię Dantego (2012), a także liczne wojaże zagraniczne (m.in. reżyserowanie Makbeta Giuseppe Verdiego we Florencji, w Palermo i Moskwie, 2002-2003).

Do Polski trafił Nekrošius po raz pierwszy w niezbyt sprzyjającym momencie. Wileński Państwowy Teatr Młodzieżowy (Valstybinis jaunimo teatras) wystąpił gościnnie ze spektaklami Wujaszek Wania oraz Pirosmani, Pirosmani... w 1986 roku w warszawskim Teatrze Dramatycznym i Starym Teatrze w Krakowie. Krytyce jego twórczość wydała się co najmniej interesująca, choć trudna w odbiorze. Andrzej Multanowski pisał o budzących sprzeciw niejasnych sekwencjach oraz mękach widza, ale kończył swoją relację wielką pochwałą: 
Po czterech godzinach maksymalnej koncentracji, skupienia intensywnego aż do bólu, to jednak zbyt wiele. Wychodzę zmęczony, ale w nastroju podobnym do tego, jaki kiedyś, przed laty, towarzyszył oglądanej po raz pierwszy Umarlej klasie Kantora, spektaklom Swinarskiego czy Grzegorzewskiego. Myślałem, że ulotnił się on bezpowrotnie (Multanowski 1986: 15).

Relację otwierał jednak przygnębiający obraz niezrozumienia u polskiej widowni:

Po tych dwóch październikowych wieczorach do dziś pozostało piekące uczucie goryczy. Wielka biało-wiśniowa sala Dramatycznego nie wypełniona nawet w czwartej części. Jakieś zbłąkane wycieczki z prowincji, umykające pospiesznie w czasie przerwy, grupki zdezorientowanych dzieci zagubione w reprezentacyjnych lożach, kilku - jak zwykle tych samych - krytyków, pewien znany reżyser - samotny reprezentant środowiska, ani jednego aktora. A potem - zażenowanie i smutek w oczach wykonawców, z lękiem wychodzących do ukłonów, bezmyślność, a może głupota, teatralnego elektryka $\mathrm{z}$ ostentacją oświetlającego przeraźliwie wyludnioną widownię, na koniec - tradycyjny kosz kwiatów, niby taki sam jak zwykle, tym razem jednak w pustce sali, wyjątkowo żałosny (ibid.: 14).

Na Pirosmanim widzów było jeszcze mniej. Wizyta Litwinów uświadomiła krytykowi zaściankowość polskiego życia teatralnego i kulturalnego. Właściwie jednak to społeczna apatia panująca w Polsce po stanie wojennym i niechęć do Związku Radzieckiego zrobiły swoje.

Powołany do istnienia przez Krystynę Meissner w miejsce zasłużonego Festiwalu Teatrów Polski Północnej Międzynarodowy Festiwal Teatralny „Kontakt” okazał się i w sensie czasu historycznego, narodzin nowej Polski i nowej Europy, i w sensie miejsca „Zszywania Wschodu z Zachodem”, jak to zamierzyła sobie Meissner, idealny dla ponownego debiutu litewskiego reżysera w Polsce. Bez wielkiej przesady można powiedzieć, że seria przedstawień Nekrošiusa zrealizowanych pod szyldem Festiwalu LIFE i Meno Fortas wstrząsnęła widzami i w znacznej mierze ustanowiła markę toruńskiego festiwalu. 1994 małe tragedie Aleksandra Puszkina Mozart i Salieri, Don Juan, Dżuma, 1995 - Trzy siostry Antona Czechowa, a potem wspaniałe inscenizacje Szekspira: 1996 - Miłość i śmierć $w$ Weronie, reedycja rock-opery na podstawie Romea i Julii, 1997 - Hamlet, 1999 - Makbet, 2001 - Otello. W tym czasie Nekrošius zdobył trzy razy Grand Prix i pięć razy nagrodę dla najlepszego reżysera „Kontaktu”. Dorobek nieporównywalny z nikim innym. Nie znaczy to, że widownia i krytyka bez oporów przyjmowała jego teatr „skomplikowanej prostoty” („sudètingas paprastumas” - według Marcinkevičiute 2002: 9), teatr „nie do końca kontrolowanej wyobraźni” (Zinowiec 1986: 30), hieroglifów, zagadek, symboli, jak pisało wielu krytyków z najbardziej kompetentnym i zafascynowanym Nekrošiusem - Łukaszem Drewniakiem na czele. 


\section{Laisvè, czyli wolność reżyserskiej lektury dramatu}

Kluczem do zrozumienia gąszczu hieroglifów, z których składają się przedstawienia Nekrošiusa wydaje się jego strategia czytania inscenizowanych utworów. W 1984 roku w ankiecie czasopisma „Kulturos barai” reżyser powiedział, że „opowieści są przecież podobne. Miłość i nienawiść, życie i śmierć - to odwieczne pytania. Dlatego też ważne jest to, co kryje się między słowami, jaka otwiera się między nimi przestrzeń” ${ }^{1}$. W tej wypowiedzi pokazał sferę swoich zainteresowań, poszukiwanie treści uniwersalnych - tematyki egzystencjalnej i metafizycznej, rudymentów ludzkiego istnienia w świecie. Zasygnalizował także relację między tekstem a inwencją reżysera-interpretatora tego tekstu wnikającego w jego ukryte znaczenia. Jak komentuje to Ramunè Marcinkevičiutè w swojej monografii zatytułowanej właśnie Eimuntas Nekrošius: przestrzeń pomiędzy słowami:

Między słowami kryje się teatr. Jego moce twórcze i jego strefa wolności [laisvės zona]. Między słowami otwiera się przestrzeń wyobraźni reżysera².

Pisałem o tym wielokrotnie, szczególnie w artykułach i esejach dotyczących Szekspirowskich inscenizacji litewskiego reżysera ${ }^{3}$. Najważniejsza sprawa dotyczy powiązania teatralnej wyobraźni Nekrošiusa dość ściśle z tekstem. To znaczy, że rekwizyty i elementy scenografii, które pojawiają się na scenie, zostały zwykle odnalezione w metaforach zapisanych w dramacie. Cała sfera żywiołów w Hamlecie: lód, woda, popiól, wosk - włącznie z żelaznym żyrandolem z płonącymi świecami na górze i powoli topniejącymi kryształkami lodu zwisającymi u dołu - została wywiedziona z tekstu Szekspira ${ }^{4}$. Podobnie jest rozwijana na wiele sposobów metaforyka miłości jako morza i muzyki w Otellu. Nekrošius $\mathrm{z}$ jednej strony wizualizuje metafory, przemienia obiekty poetyckie $\mathrm{w}$ realne przedmioty, zmysłowo odczuwane zarówno przez aktorów, jak i widzów, z drugiej - manipuluje tymi przedmiotami, wprowadzając je w sytuacje sceniczne tak, że nabierają coraz to nowych znaczeń symbolicznych i metaforycznych, budzą coraz to nowsze skojarzenia.

Kilka przykładów. W Trzech siostrach pojawiały się na scenie brzozowe polana, wyraźna aluzja do brzóz rosnących w ogrodzie domu Prozorowych. W pierwszej części spektaklu z polan została ustawiona brzozowa wieża, dziwny obiekt sceniczny wywołujący szereg skojarzeń: „wieża-posterunek, wieża-stos, wieża-piec, z zawieszonymi na niej zegarami” (Rembowska 1995: 13), w tym także najbardziej podstawowe: centrum domu. W miarę rozwoju zdarzeń wieża przeobrażała się w brzozowy trakt (drogę trzech bohaterek ku przyszłości), a w finale w trzy studnie, do których siostry wypowiadały swoje

\footnotetext{
1 „Juk siužetai panašǔs. Meilè ir neapykanta, gyvenimas ir mirtis - tai amžini klausimai. Todèl ir svarbu tai, kas slypi tarp žodžių, kokia už jų atsiveria erdvè" (Marcinkevičiutė 2002: 78, tłum. A. D.).

2 "Tarp žodžių slypi teatras. Jo kūrybinès galios ir jo laisvès zona. Už žodžių atsiveria režiseriaus vaizduotès erdvè" (Marcinkevičiutè 2002: 78, tłum. A. D.).

3 Zob. Duda: 1999; 2000; 2001.

4 Szerzej na tę kwestię spojrzała Maria Kalinowska, która wskazała istotne podobieństwa wyobraźni teatralnej Nekrošiusa do wyobraźni Adama Mickiewicza, zwłaszcza do sensualności i dynamiki świata poetyckiego Dziadów wileńsko-kowieńskich (Kalinowska 2007: 71 i n.).
} 
życzenia powszechnego szczęścia i miłości. W Hamlecie ruch żywiołów oraz zderzenie świata realnego i metafizycznego symbolizowała woda w różnych stanach skupienia, popiół (ziemia) i wosk. Słup wody spływającej w centrum sceny, woda w kielichach i kostki lodu symbolizowały dusze, życie, świat duchów, popiół zaś przeciwnie - śmierć. Król Klaudiusz grzebiący dłonią w kielichu obrazował metaforyczne grzebanie we własnym sumieniu, wirujące w powietrzu płatki spalonego papieru jako „Słowa, słowa, słowa” Hamleta wizualizowały motyw vanitas, a popiół wdmuchnięty aktorom w oczy przemieniał ich w swoistym obrzędzie przejścia w posłańców zemsty i śmierci. Ciągi metaforyczne „naczynie-ciało”, „woda/lód/kropla-dusza/duch”, „popiół/śmierć” były rozwijane w spektaklu na wiele sposobów, dość powiedzieć, że Poloniusz ginął utopiony w szklance wody, a Ofelia - w finale podwodnej ciuciubabki, goniąc dłonie-rybki królewskiej pary i dworzan. Metaforyka wodno-lodowa stwarzała także pożądany przez reżysera wymiar refleksji metafizycznej:

Mgła. Lód. Mgła przemienia się w krople wody. Kropla wody zamarza w lód. Co jest przeciwieństwem lodu? Żar, ogień. Roztapia lód. Ogień zamienia się w popiół. Podstawowe stany fizyczne. Prawa. Aksjomaty Natury. Lubię te stany. Czyste, podstawowe żywioły. Lód jest po prostu lodem. Powstaje $\mathrm{z}$ wody. To nie metafora. To coś prawdziwego, niepodważalnego. Zmienność stanów powtarza się w życiu człowieka - dzieciństwo, dojrzewanie, dorosłość, starość. Życie składa się z segmentów. Cykli. Zmienność i przemiany materii przynależą do tych stanów Natury. Na wiosnę lód przemienia się w wodę. Woda wytworzy inną formę życia. Tak to się toczy przez wieki. W scenie, kiedy Hamlet składa przysięgę, lód powinien zmieniać się w wodę - oparcie bujanego fotela powinny objąć płomienie (Nekrošius 1997: 11).

Właściwie każdy spektakl Nekrošiusa zawiera własną sferę prostych przedmiotów zwracających uwagę swoją materialnością, a z drugiej strony metaforycznością wyrastającą z ruchu na scenie, z relacji z bohaterami. Na przykład w Otellu reżyser wprawia w ruch niewinnie wyglądające drewniane niecki/miski. Kiedy zostaną położone do góry dnem, tworzą wyspę Cypr, gdy ojciec Desdemony zanosi skargę na Otella do Doży, stają się hełmami żołnierzy-świadków rozstrzygania sporu, kiedy Otello wyrusza na wyprawę przeciw Turkom, niczym tytan ciągnie na żeglarskich linach imponującą flotyllę. Później Maurowi (w znakomitej kreacji Vladasa Bagdonasa) rozważającemu sens podejrzeń wobec żony towarzyszy ogień płonący w łódce - metaforyczny ogień zazdrości w ciele żeglarza przebywającego daleko na morzu. Jago opowiadający o tym, jak Kasjo przytulał się do niego, śniąc o Desdemonie, kładzie jedną na drugą dwie łódki, wywołując u Otella odrazę zarówno do homoseksualnego podtekstu pieszczot dwóch mężczyzn, jak i obrazu żony w objęciach kochanka. W scenie finałowej łódki przemieniają się w trumny, kiedy Otello-Bagdonas zrzuca ze sceny pod stopy widzów z pierwszego rzędu - z hukiem - cztery łódki, a potem sam pada twarzą w wydrążony pień drzewa.

Zupełnie olśniewający wydaje się trop interpretacyjny podjęty w Dziadach w Teatrze Narodowym w Warszawie (2016). Z połączenia postaci Komandora z Don Giovanniego Mozarta (którego arię Mickiewicz wpisał w scenę Salonu Warszawskiego), kubistycznego pomnika poety autorstwa Zbigniewa Pronaszki (jego drewniana makieta stanęła w 1924 roku w Wilnie) oraz młodzieńca z Dziadów części I, który „powoli wrasta w kamień” i w końcu „cały stał się kamieniem”, wyprowadza Nekrošius wątek „kamiennego gościa” upiora z lodowatą piersią, arcypoety zabudowywanego w finale Wielkiej Improwizacji 
Vladas Bagdonas (Otello) i Rolandad Kazlas (Jag

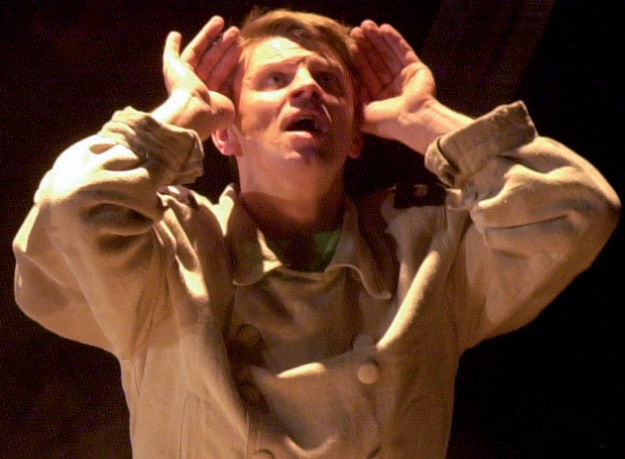

w Otellu W. Szekspira w rè. Eimuntasa Nekrošiusa,

Fot. Wojtek Szabelski. Z archiwum atru im. W. Horzycy

w sarkofag ze świeżo wydanych tomów, Gustawa-Konrada Grzegorza Małeckiego o kanciastej sylwetce podkreślanej przez ciężki, wojskowy płaszcz. Reżyser daje się ponieść wyobraźni i w efekcie widz staje przed prawdziwym dylematem percepcyjnym - jak rozwikłać te szeregi zmysłowo-poetyckich skojarzeń lawinowo docierające do jego umysłu ze sceny. Barokowe bogactwo, estetyka nadmiaru, gąszcz znaczeń to wyraziste cechy rozpoznawcze teatru Nekrošiusa.

Właśnie ze względu na reifikację i wizualizację metafor wyczytanych z tekstów, dbałość o eksponowanie naturalnej materialności prostych przedmiotów (drewna, kamieni, lodu, siekier, wideł, piły tarczowej, kartek papieru, ołówków, baniek na mleko, gimnastycznych kozłów itp.), konstruowanie ciągów metaforycznych przez używanie tych przedmiotów w nowych kontekstach, najczęściej w formie etiud-zabaw, które pozwalają nadać tym obiektom nowe, teatralne znaczenia, nazywam twórczość Eimuntasa Nekrošiusa teatrem zmysłowych metafor.

\section{Meilè ir mirtis, czyli aktorzy Nekrošiusa}

Cały zmysłowo-materialny świat w przedstawieniach artysty z Meno Fortas uruchamiają aktorzy. Intensywność ich obecności na scenie jest uderzająca, tak jakby poruszali się jak Romeo i Julia w Nekrošiusowej, muzycznej wersji tragedii Szekspira - wyłącznie 
między skrajnymi biegunami miłości (meile) i śmierci (mirtis). Charyzma i cielesność, nadekspresja gestyki i ruchu sprawiają, że mamy do czynienia z autorską odmianą aktorstwa cielesno-performatywnego, tzn. takiego, które stoi w opozycji do zakorzenionego $\mathrm{w}$ europejskim teatrze dramatycznym aktorstwa realistyczno-psychologicznego, a jego opozycyjność i siła ekspresji opiera się na dążeniu do wizualnego ujęcia z wykorzystaniem możliwości ciała motorycznego i energetycznego. Przy czym nawet tam, gdzie aktor był poddawany niekoniecznie przyjemnym bodźcom zmysłowym kojarzącym się ze sferą sztuki performansu, reżyser nie zmierzał do jego dręczenia czy wystawienia na ból. W najbliższej sztuce performansu inscenizacji Hamleta Nekrošius negocjował z aktorami rozwiązania sceniczne:

W Hamlecie nikogo nie torturuję. Andrius Mamontovas staje bosymi stopami na bryle lodu, ale przecież mógł tego nie robić. Rozmawialiśmy podczas prób i powiedziałem mu: „Musisz mieć jakiś punkt odniesienia. Popiół to śmierć, lód to życie”. I zapytałem: „Czy przyjmujesz to rozróżnienie i swoje miejsce $\mathrm{w}$ takim świecie? Czy możesz rozmawiać z tymi rzeczami jak z drugim człowiekiem?”. Zastanowił się i odrzekł, że tak. Zgodę na sceny tego typu osiągam wyłącznie dzięki porozumieniu $\mathrm{z}$ aktorem, na nic nie wpływam i nigdy nie naciskam (Nekrošius 1998: 15).

Naprawdę uderzająca jest w twórczości teatralnej Nekrošiusa intensywność scenicznej obecności, jakość i elegancja ruchu aktorów. Wynika to i z wrodzonych warunków fizycznych wykonawców, takich jak męski, brodaty Vladas Bagdonas w rolach Ducha ojca czy Otella, i z kontrastów między aktorami wchodzącymi w interakcje. Na przykład jedynym nieaktorem w Elsynorze był grający Hamleta Andrius Mamontovas, w przydługim, czarnym kaftanie, z irokezem na głowie, lider zespołu Foje (po polsku Foyer), trochę niezgrabny, kanciasty, ale z wielką estradową charyzmą objawiającą się naturalnym, tzn. nieteatralnym byciem na scenie. Tak jak Władimir Wysocki w moskiewskiej inscenizacji Lubimowa (1972), Mamontovas - do dziś kontynuujący karierę muzyczną, choć już tylko solową - uwiarygodniał postać księcia duńskiego swoją prywatną biografią. Z kolei w Otellu Bagdonasowi partnerowała także nie aktorka, tylko primabalerina Eglè Spokaitė, solistka litewskiego Teatru Narodowego Opery i Baletu.

Eksponowanie ciała motorycznego jest możliwe w teatrze Nekrošiusa dzięki konstruowaniu ludycznych sytuacji scenicznych - swoistych gier i zabaw pozwalających plastycznie wizualizować interakcje między postaciami, nieraz z użyciem rekwizytów. W Trzech siostrach Baron Tuzenbach (Vladas Bagdonas) je ostatnią wieczerzę w towarzystwie Iriny (Viktorija Kuodytė). Je łapczywie, wylizuje talerz, potem wprawia go w ruch obrotowy, wirujący talerz, czyli teatralny bąk, wywołuje dziecięcy zachwyt Iriny. Bąk wiruje coraz wolniej, przewraca się z brzękiem. Irina jest zrozpaczona. Brzęk brzmi jak wystrzał z pojedynku barona z Solonym, który u Czechowa odbywa się, jak wiadomo, poza sceną.

W Makbecie Banquo (Vidas Petkievičius) zostaje napadnięty przez morderców. Aktor pełznie na brzuchu schowany za długim drewnianym balem. Mordercy wbijają kilkanaście siekier w drewniany bal, w drewno-ciało. Banquo „naszpikowany” żelazem zastyga. W zdekomponowanym obrazie zabójstwa oddzielnie pełznie aktor-dusza, oddzielnie spoczywa wstrząsane dosłownie ciosami siekier drewno-ciało. Człowiek-drzewo zostaje zabity-ścięty. Ogólna metafora człowieka jako drzewa została wywiedziona - nie muszę chyba tego do- 
dawać - z przepowiedni o tym, że Makbet nie zginie, póki Las Birnamski nie przyjdzie po niego.

I trzeci przykład: postać Poloniusza w Hamlecie. Grający go Povilas Budrys w wywiadzie dla „Didaskaliów” powiedział:

Miałem grać człowieka, który mozolnie niczym żuk wczołguje się na górkę, tocząc przed sobą kulkę z błota. Wyobrażenie tego ruchu i związanego z nim syzyfowego wysiłku było punktem wyjścia. Potem usunęliśmy tę formę, do spektaklu trafily sceny, w których przygotowuję salę tronową do audiencji, rozstawiam krzesła i stoły, wtaczam kule (Zmysły i słowa 1998: 57).

Z kolei grana przez Viktoriję Kuodytė Ofelia w tym samym przedstawieniu nieustannie wchodziła w zabawy a to $\mathrm{z}$ ojcem (nieprzyjemne „spędzanie płodu” w misce z gorąca wodą), a to $\mathrm{z}$ bratem (w lokomotywę - $\mathrm{z}$ fajką i skrzynią podróżną), a to z dworem królewskim (w rybę, która utonęła). Z piskiem, dziecinnym zadziwieniem, wkładała także rękę pod spadające na środku sceny krople wody - znak obecności świata duchów. Jak widać, płaszczyzny realnych działań i metaforycznych znaczeń przenikają się w spektaklach Nekrošiusa nieustannie.

Gdybym miał wskazać jakieś części ciała uprzywilejowane w twórczości litewskiego reżysera, byłyby to nagie dłonie i stopy. W Don Juanie (jednej z części Małych tragedii Puszkina) tytułowy bohater grany przez Algirdasa Latenasa podrywa rezolutną dziewczynkę, łaskocząc jej stópki. W finale dziewczynka okazuje się Śmiercią, która teraz czerni jego stopy. Z kolei gest ręki wyciągniętej ku spadającym kroplom wody to jeden z najbardziej zapadających w pamięć motywów Hamleta. W Dziadach wzdłuż sceny ciągnie się szereg drżących w nurcie niewidzialnej rzeki rąk wiejskiej gromady prowadzonej przez Guślarza (Marcin Przybylski). Jacek Kopciński widział w motywie ręki w tej inscenizacji klucz do interpretacji całości, rejestrując w II części Dziadów drżący palec Sowy (Magdalena Warzecha) nad głową Złego Pana, bandażowany przez Guślarza i przemieniony w żałosne zawiniątko - symbol dziecka zamarzłego zimą, w IV części - dłonie Gustawa i Księdza „sięgające do wspólnego talerza w jakiejś momentalnej komunii” (Kopciński 2016: 11), a w III części - wysuniętą z „dziwnej trumny”, czyli grobowca z książek, komicznie wciąż żywą rękę poety wpisującego autografy innym poetom. Naczelny „Teatru” pisał:

Wyprostowane dłonie o rozwartych palcach będą w spektaklu Nekrošiusa skrzydłem, gałęzią drzewa, pazurami, ostrzem miecza, powierzchnią migotliwej wody w niewidzialnej strudze; dłońmi ludzi cierpiących i umarłych, walczących, modlących się i błogosławiących. A przy tym zawsze pozostaną odbiciem dłoni poety z wileńskiego pomnika (ibid.: 8).

Przez wiele lat myślałem, że tylko litewskie aktorki potrafią dźwignąć zadania postawione przez reżysera: stworzenia dziewczęco-zmysłowych solowych bohaterek (jak Viktoriji Kuodyte Laura w Małych tragediach, Julia w Miłości i śmierci w Weronie, Ofelia w Hamlecie) czy swoistych kobiecych ansambli (wspomniana Kuodytė wraz z Dalią Michelevičiutė i Aldoną Bendoriutė w Trzech siostrach albo zaskakująco młode Wiedźmy w Makbecie grane przez siostry Viktoriję i Gabrielę Kuodytè oraz Margaritę Žemelytè). W warszawskiej inscenizacji Dziadów okazało się, że pod ręką litewskiego reżysera także polskie wykonawczynie przemieniają się w cudowny sposób w przykuwające uwagę dziewczęcą świeżością postaci. Tak się stało w kreacjach Pauliny Korthals i Pauliny Szostak w rolach Dzieci Księdza w IV 
części arcydramatu Mickiewicza. O ile jednak swoiste odczarowanie granych zwykle mniej lub bardziej sztucznie przez prawdziwe dzieci ról trudno uznać za reżyserskie osiągnięcie większego kalibru (aktorskie jednak jak najbardziej), o tyle już wykreowanie przez Wiktorię Gorodeckają Maryli jako pełnokrwistej, zapadającej w pamięć postaci samotnej kobiety dzielnie idącej (ba, płynącej tanecznym krokiem) przez świat, trzeba uznać za majstersztyk. Przywołajmy tę zmysłową postać stojącą pod wielką makówką w muślinowej spódniczce baletnicy i turkusowym trykocie, rysującą palcem w powietrzu literę „A” - początek imienia kochanka. Dodajmy tę samą postać w już białym trykocie z rozwianą burzą włosów w finale spektaklu, kiedy przychodzi ponownie na Dziady.

Podczas gdy nieruchomy pod drzewem Guślarz - pisze Kopciński - monotonnie opisuje ów straszny moment, kiedy upiory wydobywają się z grobów, ona pląsa po abstrakcyjnej łące. Nagle wkłada głowę do jednej z zapadni i śpiewa niesamowitym, ludowym i wschodnim głosem niewypowiedzianą frazę z jej pierwszego monologu: „Witajże, ma jaskinio”. Na ciągle świeżych grobach rozlega się pieśń nieśmiertelności (ibid.: 11).

Czy ktoś kiedyś tak pokazał Marylę? Tę nudną, prozaiczną, rozczarowującą odrzuceniem wielkiego poety inkarnację Maryli Wereszczakówny?

\section{Lietuvos balsai, czyli muzyczność}

Pół żartem, pół serio można powiedzieć, że przez chwilę mogło się wydawać, że Nekrošius stanie się litewskim Castorfem. Przypomnijmy muzykę Pink Floyd w etiudzie szkolnej, a potem oszałamiający sukces rock-opery Miłość $i$ śmierć $w$ Weronie (premiera: 1982), ogromne kolejki pod wileńskim teatrem, tłumy koczującej nocami młodzieży, materace, granie na harmonijce i wspólne śniadania pod gołym niebem. Wyobraźmy to sobie: szczyt potęgi Związku Radzieckiego, epoka Breżniewa, a w środku „teatralnej republiki” (jak nazywał Litwę rosyjski „Tieatr”) grają „zgniłą”, zachodnią muzykę. Ramunè Marcinkevičiute pisała o tym spektaklu:

W 1982 roku rock-opera Mitość i śmierć w Weronie byla i o wolności. O wolności tworzenia rock-opery. O wolności słuchania innej muzyki. O wolności kochania i umierania w Weronie. O wolności tworzenia i grania Szekspira za cenę naruszenia tekstu i z ryzykiem zdobycia „nagrody” za takie „wolnomyślicielstwo” zapisanej w kodeksie karnym (Marcinkevičiute 2002: 149).

Kiedy po latach Nekrošius wznowił przedstawienie, okazało się, że próby czasu nie przetrwała muzyka Kęstutisa Antanèlisa i Sigitasa Gedy. Przetrwał Szekspir oraz teatralne myślenie inscenizatora o sferze dźwięków wydawanych przez ludzi i przedmioty. Najlepszy przykład to audiosfera Nekrošiusowych Dziadów w Teatrze Narodowym w Warszawie w 2016 roku. Co się pamięta? Na pewno obrazy-hieroglify, ale i dźwięki: dziecięce okrzyki dziewczynek w domku Księdza, wspaniały sopran Wiktorii Gorodeckiej, dźwięczne „A”, „A-litera”, stylizowany na ludowo zaśpiew „Witajże, ma jaskinio!”, drapanie paznokciami desek sceny przez Guślarza, szemrzący, podziemny strumień, uderzenia kropli wody, plusk, bezdźwięczne drżenie dłoni, lawinę puknięć spadających na scenę ołówków, ciężkie wes- 
Povilas Budrys

w Fauście J. W. Goethego

w reż. Eimuntasa Nekrošiusa

Fot. Magdalena Kujawa

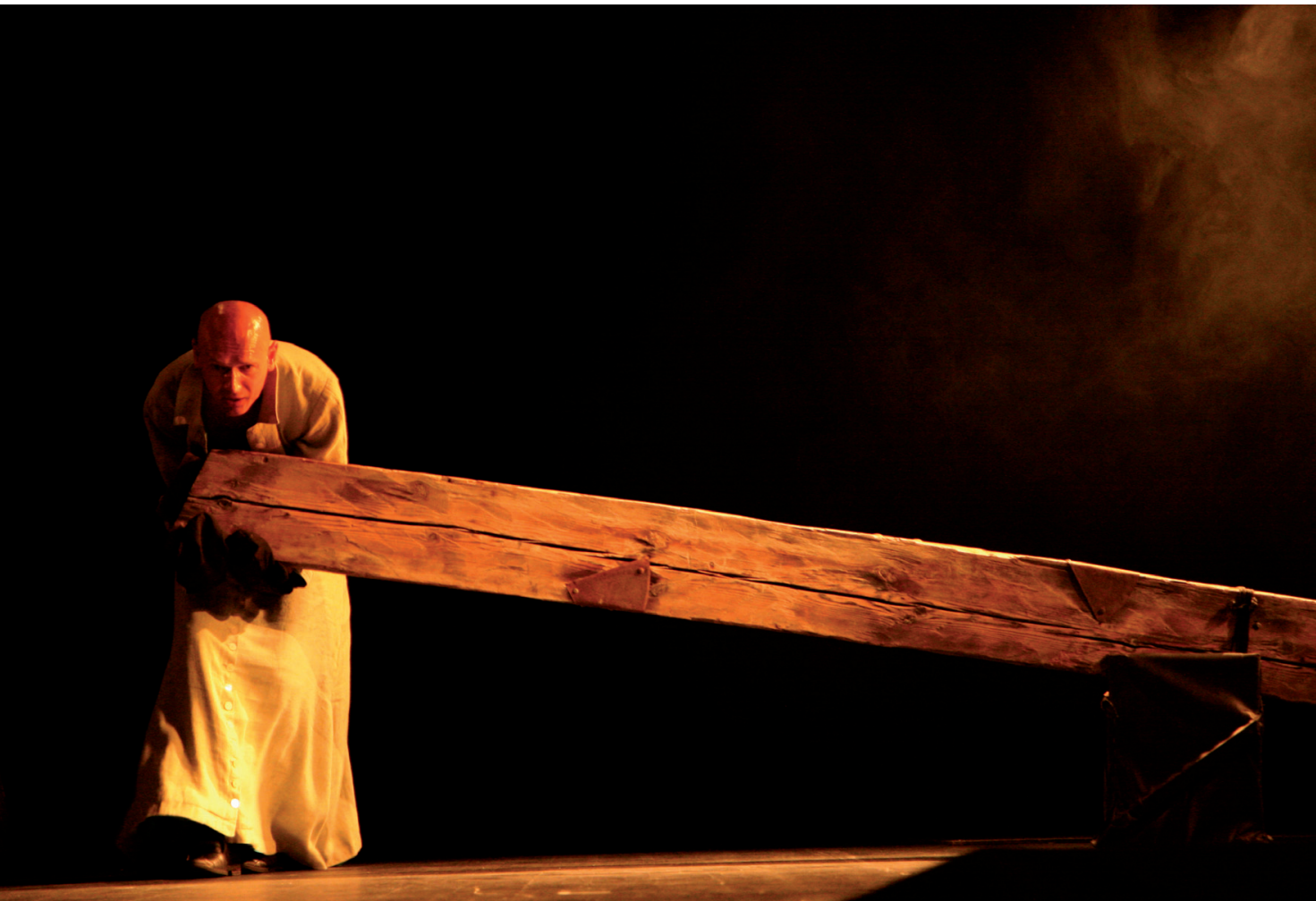

tchnienia otwierającej się harmonii, chropawo śpiewaną piosenkę Gustawa „Jakże kocha dziewczyna / Co chwilę przypomina”, czyste, mocne brzmienie walca Nad pięknym, modrym Dunajem w scenie balu, a potem monumentalną arię Komandora z Don Giovanniego Mozarta, uderzenie pioruna, stukot bocianich jaj używanych jako golfowe piłki, monet i srebrnych kulek odstraszających upiory, tykanie zegara, podpowiadane przez diabły tematy Wielkiej Improwizacji: „A słowa?”, „A pieśni?”, „A nieśmiertelność?”, „A poeci?”, „A skrzydła czucie?”. Kaskady dźwięków, przerywane pauzami milczenia, układające się w osobną warstwę, której nie sposób zrekonstruować w pełni, gdyż wdziera się mimowolnie do ucha widza.

Teatr Nekrošiusa jest zanurzony w muzyczności, która zawsze przejawia się w audiosferze codzienności, często przechodzącej w metaforę, jak w ikonicznej już scenie rozmowy Mozarta (Algirdas Latėnas) z Salierim (Vladas Bagdonas) w Małych tragediach Puszkina. Ten pierwszy klęczy, podtrzymując kolanem ciężkie cielsko fortepianu i przesuwając z toskotem koraliki drewnianego liczydła. Rachmistrz-wyrobnik. Ten drugi - wirtuoz - giętką witką wygrywa w powietrzu bez wysiłku improwizowane, lekkie arcydzieła. W Hamlecie z kolei w podkładzie muzycznym przewijają się wciąż dwie arie z opery La forza del destino (Moc przeznaczenia) Giuseppe Verdiego. Pierwsza La vergine degli Angeli w scenie, gdy Hamlet rozbija bryłę lodu od Ducha ojca i wyjmuje z niej nóż, w scenie, gdy mówi, że stracił radość życia i sypie popiół na kartkę, a także podczas spotkania Ofelii z Gertrudą, a za chwilę rozmowy matki z Hamletem, po czwarte, w scenie rozmowy Hamleta z matką (i z trupem 
Poloniusza jako rekwizytem), po piąte, po śmierci Hamleta w finale spektaklu. Powtarza się wciąż rozbrzmiewająca $\mathrm{z}$ offu fraza:
La vergine degli angeli
Mi copra del suo manto
E me protegga vigile
Di dio l'angelo santo

Dziewica od Aniołów

Okrywa mnie swoim plaszczem

I opiekuje się mną troskliwie

Święty anioł Boży

Za lejtmotyw Hamleta Nekrošiusa można uznać temat ciepłej i szorstkiej zarazem miłości rodzicielskiej. Nie ma żadnych wątpliwości, że Poloniusz kocha Ofelię, a Gertruda syna, nie ma też cienia wątpliwości, że duchy i boska siła sprawują pieczę nad porządkiem świata. Ludzie są na ogół niewinni, rzeczy toczą się swoim trybem, zawsze ku śmierci.

Drugi utwór w Hamlecie pochodzący z opery Verdiego to aria modlącej się o spokój duszy Donny Leonory Pace, pace, mio Dio, śpiewana przez Aktorkę po śmierci Ofelii (Łukasz Drewniak omyłkowo pisał o wykonaniu Ave Maria, oba utwory są rzeczywiście bardzo podobne). Śmierć nie jest zła, zdaje się mówić reżyser i w tym, i w innych swoich przedstawieniach. Po życiowej szarpaninie wyrwanie się spod twardej rodzicielskiej ręki, spod „pocisków losu” musi przynieść ulgę - spokój.

Od czasów premiery Kwadratu w 1980 roku za opracowanie muzyki w spektaklach Nekrošiusa odpowiadał najczęściej Faustas Latenas. Do ścisłego grona jego współpracowników należą także żona - Nadežda Gultiajeva i syn - Marius Nekrošius zajmujący się scenografią. Z żoną i synem pracował nad warszawskimi Dziadami, muzykę opracował Paweł Szymański, z którym Nekrošius spotkał się już w 2013 roku, kiedy wyreżyserował w Operze Narodowej w Warszawie prapremierową inscenizację jego Qudsji Zaher - muzycznej opowieści o afgańskiej imigrantce, która rzuca się ze statku w wody Bałtyku i odkrywa podwodny, zaludniony duchami topielców świat. Opera nie miała najlepszych recenzji, a litewski reżyser mógł przeczytać o sobie to, co zawsze słyszał od widzów po raz pierwszy oglądających jego spektakl:

Eimuntas Nekrošius w swojej inscenizacji też żongluje na granicy rzeczywistości i symbolu. To mocny i miejscami bolesny spektakl (zwłaszcza w realistycznym prologu), rodem z zupełnie innego świata. Nekrošius buduje opowieść oszczędnymi środkami. Wystarczą mu kamienie, grabie, halogen, imitacja łodzi, porozrzucane kapoki. Teatr odrębny, w którym istotni są ludzie - ich emocje i historie. Tylko czy aby Nekrošius przypadkiem nie snuje własnej uniwersalnej opowieści, trochę na uboczu tej Szymańskiego i Drygasa? I czy rzeczywiście zależy mu na nawiązaniu dialogu z partyturą muzyczną (Hawryluk: 2013) ? ${ }^{5}$

\footnotetext{
5 Niezadowolona z formy inscenizacji była także Dorota Szwarcman (2013): „Wizja litewskiego reżysera i jego współpracowników zamiast wyjaśniać, mocno komplikuje".
} 


\section{Dvasiai ir žmonès, czyli duchy i ludzie}

Najbardziej zaskakującą sceną Makbeta w reżyserii Eimuntasa Nekrošiusa, granego w maju 1999 roku na dużej scenie Teatru im. Wilama Horzycy był moment przyjścia na dwór królewski widm Duncana (Ramūnas Rudokas) i Banqua (Vidas Petkevičius). Weszły na scenę dwa duchy z rozjaśnionymi twarzami, z zadartymi głowami podziwiające złocenia portalu sceny, udającego tym razem wnętrze królewskiego zamku Makbeta. Przed śmiercią Duncan wyglądał znacznie gorzej - jak król-mumia, blady, kamienny posąg. Po śmierci - nomen omen - zaczął żyć pełnym życiem. Łukasz Drewniak zatytułował swoją recenzję tego Makbeta z dziewczęco pięknymi wiedźmami, gradem polnych kamieni spadających na scenę i mrożącym krew w żyłach królem-mordercą, Nekropolis (Drewniak: 1999). Trudno o trafniejszą grę słów: miasto Nekrošiusa i miasto umarłych. W tym jednym słowie mieści się zarówno idea nierozerwalnej więzi między życiem i śmiercią - dwiema stronami jednej monety-świata, jak też świętych obcowanie, tzn. definiująca obrzęd dziadów ontyczna więź pomiędzy żywymi i umarłymi.

Z przekonania reżysera o wielowymiarowości świata i jego metafizycznej głębi rodzą się w jego teatrze fantastyczne wprost wizje sceniczne, jak np. rozgrywający się przy akompaniamencie potężniejącego Miserere finał Makbeta. Wiedźmy, mordercy oraz ich ofiary skupiają się wokół wanienki, w której z sykiem zatapiana jest rozgrzana do czerwoności cegła. Najprostszy rytuał umierania. Stygnięcie i przemiana żywej „istoty” w materię. Entropia. Potem wszystkie postaci jedna po drugiej są układane jak do snu z kolanami uniesionymi do góry. Najmłodsza z wiedźm - ta, która nie chce wierzyć, że śmierć jest nieodwracalna, stawia na sztorc drewniane polana-nagrobki przy ciałach zmarłych. Banquo klęczy zgarbiony z siekierą-nagrobkiem wbitym w plecy. Tak buduje się miasto umarłych. Już wiemy Nekropolis. Dla litewskiego reżysera śmierć nie jest jednak końcem. Kiedy grzmi Miserere, a białe światło reflektora oślepia widzów, w mieście umarłych wyrasta nowe drzewo.

Cykl życia i śmierci, umierania i odradzania nie kończy się nigdy. Jednostkowe istnienia powracają do materialno-duchowej puli uniwersum i gra może się zacząć od nowa. Uderzające jest podobieństwo wielu teatralnych obrazów i światopoglądu Eimuntasa Nekrošiusa do jednej z myśli Friedricha Hebbla:

Życie jest wielkim stru mi en i e m, indywidualności są kropla mi, ale tragiczne [indywidualności] są k a w a ł k a m i lo d u, które muszą się na powrót roztopić i, aby to było możliwe, [najpierw] oderwać od siebie i rozkruszyć w p ył (Lehmann 2013: 172).

\section{Bibliografia}

Drewniak, Łukasz 1999. „Nekropolis”. Didaskalia 23.

Duda, Artur 1999. „Ludzie jak drzewa, ludzie jak kamienie”. Przegląd Artystyczno-Literacki 9.

— 2000. „Nawet szron może zapłonąć. 'Hamlet' Eimuntasa Nekrošiusa - reżyserska interpretacja tragedii Szekspira”. W: Janusz Skuczyński (red.). 80 lat teatru w Toruniu. Toruń: Wydawnictwo UMK.

- 2001. „Lekcja czytania Szekspira”. Teatr 9. 
Hawryluk, Jacek 2013. „Qudsja Zaher skacze do Battyku”. Gazeta Wyborcza. http://wyborcza. pl/1,75410,13784965,Qudsja_Zaher_skacze_do_Baltyku.html [12.04.2018].

Kalinowska, Maria 2007. „Mickiewiczowskie wizje egzystencji - pamięć jako ocalenie”. W: Joanna Kamper-Warejko, Joanna Kulwicka-Kamińska, Katarzyna Nowakowska (red.). Z przeszłości i teraźniejszości języka polskiego. Księga pamiątkowa dedykowana Teresie Friedelównie. Toruń: Wydawnictwo Naukowe UMK

Kopciński, Jacek 2016. „Dusza z ręki poety”. Teatr 5.

Lehmann, Hans-Thies 2013. Tragödie und dramatisches Theater. Berlin: Alexander Verlag.

Marcinkevičiutè, Ramunè 2002. Eimuntas Nekrošius: erdvè už žodžių. Wilno: Scena Kultūros Barai.

Multanowski, Andrzej 1986. „Jak daleko stąd, jak blisko”. Teatr 12.

Nekro ius, Eimuntas 1997. „Hamlet jest młody. Z Eimuntasem Nekrošiusem rozmawia Ramune Marcinkevičiute”. Didaskalia 19-20.

— 1998. „Aktor, dywan i gwiazdy. Z Eimuntasem Nekro iusem rozmawia Łukasz Drewniak”. Didaskalia 23.

Rembowska, Aleksandra 1995. „Wieża”. Teatr 7-8.

Szwarcman, Dorota 2013. „Opera z dna morskiego”. Polityka 07.05. http://www.polityka.pl/tygodnikpolityka/kultura/teatr/1541849,1,recenzja-spektaklu-qudsja-zaher-rez-eimuntasnekroius.read [12.04.2018].

Zinowiec, Mariusz 1986. „Jestem, ponieważ pamiętam”. Teatr 6.

Zmysły i słowa 1998. „Z aktorami Eimuntasa Nekrošiusem rozmawiają Łukasz Drewniak i Agata Ganiebna”. Didaskalia 27. 